\title{
EVALUATION OF THE INCEST CASES WHO APPLIED TO MERSIN UNIVERSITY MEDICAL FACULTY DEPARTMENT OF FORENSIC MEDICINE IN 2019
}

\author{
Gökhan AKTÜRK * \& Hakan KAR ** \\ * M.D., Research Assistant, Mersin University, Department of Forensic Medicine, \\ Turkey,e-mail: gokhanakturk92@gmail.com, \\ ORCID ID: https://orcid.org/0000-0002-0945-8195 \\ ** R M.D., Professor, Mersin University, Department of Forensic Medicine, \\ Turkey,e-mail: hakankar@mersin.edu.tr \\ ORCID ID: https://orcid.org/0000-0002-8790-6563
}

Received: 18 March 2021; Accepted: 30 March 2021

\begin{abstract}
Incest relationship, which has many different definitions, is a form of sexual abuse that is more difficult to manifest and its effects on the victim are much more severe. In our study, it was aimed to develop solutions by evaluating the sociodemographic and forensic medical characteristics of the incest victims who were sent to Mersin University Forensic Medicine Department. Method: The forensic investigation documents and medical reports of 34 incest cases that were sent to us for forensic reports with the allegation of sexual assault between January 2019 and January 2020 were analyzed retrospectively. Findings: It was found that most of the cases $(85.3 \%, n: 29)$ were women, average age being 15.41 , with the majority $(41.2 \%, n: 14)$ between the ages of $6-12$. It was observed that in $44.1 \%$ of the cases ( $n: 15)$ the defendant was the victim's biological father, in $47.1 \%$ (n:16) of the cases the incident took place in the shared house where the victim and the defendant lived. In $32.4 \%$ of the cases ( $n: 11$ ), the incident was reported by school counselors, the person to whom the victim told the event first was most frequently their mother $(35.3 \%, n: 12)$. In $70.6 \%$ of the cases ( $n: 24)$, the first person to whom the victim told the incident supported the forensic reporting process. Biological evidence was detected in $8.8 \%$ ( $n: 3$ ) of the cases, the victim's mental health deteriorated in $61.8 \%$ (n: 21) of the cases, most common psychopathology being Post Traumatic Stress Disorder (41.2\%, n: 14). Conclusion: Our study reveals the importance of schools, where children can communicate with others, in the emergence of incest. On that account, it should be ensured that children continue their education and benefit from guidance services. All teachers, especially counselors, should be made aware on the matter of sexual abuse of children. In addition, "systematic sexual education" for children should be included in the curriculum. Since incest cases are mostly reported late, more often than not biological evidence cannot be obtained. The occurrence of psychopathology in most of the victims shows the importance of mental evaluation. In addition, it should be ensured that all procedures, including clinical treatment, are
\end{abstract}


carried out in centers where multidisciplinary approach can be provided, to prevent secondary suffering due to reinterrogations and examinations of the victim in the judicial process.

Keywords: Forensic Medicine, incest, domestic sexual abuse, child abuse, sexual violence

\section{INTRODUCTION}

Sexual violence refers to a wide spectrum that includes many behaviors from the mildest to the most severe. In its classified definition; The penetration of the penis with the vulva, anus or oral area, contact of the penis, vulva or anus with the mouth, anal or vaginal penetration of a hand, finger or an object, committed against a person with no consent or whose consent was not valid; Intentional contact with the genitals, anus, groin, breasts, inner thighs or buttocks directly or through clothing, secret monitoring or viewing, and any kind of verbal or behavioral sexual harassment that does not involve physical contact (Basile \& Saltzman, 2002)(Kar \& Ozdemir, 2019). Sexual abuse is the use of a child who has not completed his psychosocial development for sexual stimulation by an adult. Among the types of child abuse, it is stated that majority of sexual abuse remain hidden in which only $10 \%$ of incest cases are reported (Dokgoz \& Polat, 2019) (Dokgoz et al., 2008). Incest is almost as old as human history, its definition; It is one of the most prevalent cultural taboos in almost all societies, showing cultural, religious, historical, and interdisciplinary differences (Ipek, 1996)(Guvenc, 2005). In addition, incest is a form of sexual violence that is the hardest to emerge and has much more severe effects on the victim.

\subsection{The Definition of Incest}

When examined etymologically, incest originates from the Latin word Incestus: "unclean, dirty" (Simpson\&Weiner 1989). In our language, the meaning of the dictionary is defined as "forbidden relationship within the family" by the Turkish Language Institution and it has been stated that it is transmitted from French "inceste" (Türk Dil Kurumu).

Many definitions of incest are made by different disciplines. Although the definition of "sexual contact and relationship between family members who are not married to each other" (Mayer, 1983) does not discriminate between children and adults for incest, many definitions define incest as child abuse. Whether or not they have blood ties, sexual intercourse between biological or step-parents and children, grandparents and grandchildren or siblings (Gok, 1991), those who are a parent figure, have power and authority in the family life and with whom the child has a trust relationship, (Bozbeyoglu et al., 2009), the abuse of a large group of relatives and relatives who have a parental dignity and authority over the child, as well as abuse of the child with relatives who have blood ties with the child (Cooper \&Cormier, 1982), sexual abuse of anyone whom the child trusts (mother's boyfriends, friends' fathers, family friends, teachers and doctors etc.) (Search, 1993)(Tutunculer, 2011). The definitions are generally differing about who the subject of incest is or what its limits are. Incest, which is defined in the most limited sense between parents and children, between siblings, and between grandparents and grandchildren, is defined as the sexual abuse of anyone whom the child trusts in the broadest sense.

\subsection{Legal Regulations of Incest Crime}

Although incest is not defined as a particular crime in our legal system, in article 129 under the heading "Relationships" in the "Prohibitions Regarding Marriage" section of the Turkish Civil Code; marriage is forbidden, 1. Between ancestor and descendant; between 
siblings; between uncle or aunt and their nieces or nephews, 2. Between one of the spouses and the ancestors or descendants of the other, even if the marriage has ended, 3 . With one's adoptive parents, or with one of their descendants or spouse. Although the mentioned prohibitions have a counterpart in the Turkish Civil Code, it is seen that in the Turkish Penal Code consensual sexual intercourse between relatives who are of age and are not legally allowed to marry each other is not regulated as a crime. In article 102, under the heading "Sexual Assault" in the third paragraph and the subparagraph $\mathrm{c}$ of the Turkish Penal Code; if the sexual violation is "committed against someone who areconsanguineous to them or theirin-law relatives, including third degree relatives, or is committed by the victim's step-father, step-mother, step-sibling, adoptive or adopted family...", then the punishments would be increased by half, in article 103, under the title of "Sexual Abuse of Children" in the third paragraph of the Turkish Penal Code, it has been stated that if the sexual violation is c) "committed against someone who are consanguineous to them or their in-law relatives, including third degree relatives, or is committed by the victim's step-father, step-mother, step-sibling, adoptive or adopted family...", d) "committed by guardians, educators, caregivers, foster families or people who provide health care or who are obligated to provide protection, care or supervision..." then the punishments would be increased by half. It also has been stated in the Turkish Penal Code, under the title "Sexual Intercourse with a Minor", the second and third paragraphs of the 104th article; that "If the violation is committed by someone who is legally not allowed to marry the victim, then the sentence would be ten to fifteen years of jail time, without the need of any complaints", "if the offense is committed by someone who undertakes the pre-adoption care of the child before adoption, or who has protection, care and supervision duties within the framework of being a foster family, a penalty will be imposed according to the second paragraph without the need of any complaints".

As is seen, unlike the other violations regarding one's sexual inviolability, it changes the severity of the punishment if incest is committed against to a child rather thanagainst to an adult.

\subsection{The Definition of Incest in Our Study}

Cases of sexual violence that took place by taking advantage of the trust that was established due to kinship relation (including blood, in-laws, and stepfamily) were evaluated as "incest".

\section{AIM}

This study is aimed to investigate the physical and mental effects of incest on the victim, reveal itssociodemographic and medico-legal characteristics, and to propose some measures and solution offers that can be taken to reveal and prevent incest.

\section{METHODOLOGY}

The forensic investigation documents and medical reports of 34 incest cases that were sent to us for forensic reports with the allegation of sexual assault between January 2019 and January 2020 were analyzed retrospectively. The physical examination findings of Forensic Medicine and other departments' and the statements of victims, witnesses and defendants in the judicial files and the previous reportsof the victimsand the perpetrators and all data were analyzed statistically. This research was conducted with consideration of Declaration of Helsinki principles.

\section{FINDINGS AND DISCUSSION}

People who tend not to report the sexual violence towards themfor various reasons prevent the determination of the true prevalence. Incest is a type of sexual violence that is more 
difficult to come out and its various effects on the victim are much more severe. According to the data of the World Health Organization, 150 million girls and 73 million boys were forced to have sexual intercourse before the age of 18 or were exposed to any form of sexual violence in 2002. 20-30\% of girls and about 5-10\% boys were exposed to abuse in their childhood, and $20-25 \%$ of these sexual abuse cases were incestuous according to other studies worldwide (Bozbeyoglu et al., 2009)(Bulut, 2007)(Canat, 1994). The rate of incest in all sexual abuse / assault cases was found to be similar in our study. Out of the 140 cases that were submitted to our Forensic Medicine Department with the allegation of sexual abuse / assault for reporting, 34 cases $(24.2 \%)$ met the criteria of our study's definition of incest.

While $82-86 \%$ of the child victims of sexual abuse and incest were found to be girls, and $14-18 \%$ of were boys according to the some local incest studies; it was also shown that females were exposed to incest 5 times more than men, on average (Canat, 1994). Studies around the world have also found that sexual abuse and incest are much more common in girls (Gokten, 2011)(Yildirim et al., 2014)(Kocak\&Alpaslan, 2015). Most of the incest victims $(85.3 \%, \mathrm{n}: 29)$ were female, and the percentage of male cases was $14.7 \%$ (n: 5) in our study and this percentages are concordant with the relevant literature. The possible reason for lower rates of sexual abuse of male gender,ispresumed that the cases of male sexual abuse cases are tend to beunderreported than the female sexual abuse cases. The reasons for this were stated as males having a harder time to voice their experiences due to fears of not being believed, getting punished or being stigmatized as homosexual in the society (Gencer et al., 2016)(Ertur\&Yayci, 2011).

When the distribution of sexual abuse and incest cases by age groups were evaluated, studies showed that the age onset in victims of sexual abuse and incest was mostly 5-12 years old (Canat, 1994)(Eker et al., 1993). Findings of our study are concordant with the literature, and the average age was found to be 15.41 and abuse started mostly in the 6-12 age range $(41.2 \%, \mathrm{n}: 14)$. The reasons underlyingof why incest is more common in childhood has been shown as the fact that children are small and vulnerable, can be easily deceived and scared, moreover, children are quick to trust, and they do not take it into account that they can be harmed (Gregory-Bills \&Rhodeback, 1995).

According to the literature regarding to the degree of propinquity of the offender to the victim, father-daughter incest appears to be the most common form of incest, incest between siblings being the second most common and mother-son incest the least common type (Sezgin, 1993)(Polat, 2006)(Fischer \&Mcdonald, 1998)(Cyr et al., 2002). The findings obtained in our study were also parallel with the literature, it was found that the aggressor was mostly the victim's biological father $(44.1 \%, \mathrm{n}: 15)$, and in one case he was their stepfather.

In studies on the age and gender distribution of the aggressor, it was stated that almost all of the aggressors were male, according to age groups, $66 \%$ were 25 years old and over, and in another study, the majority of the perpetrators of incest $(87.5 \%)$ were between the ages of 20-59 (Sezgin, 1993)(Quarshie et al., 2017). In our study, all the aggressors were male and upon examining the aggressors whose exact age was known (58\%, n: 20), it was found that the youngest was 15 years old, the oldest was 64 years old, and the majority was between the ages of $20-40(65 \%, \mathrm{n}: 13)$.

Considering the distribution of the cases according to family structures in our study, it was observed that $76.5 \%$ (n: 26) of the cases were in the nuclear family and $23.5 \%$ (n: 8 ) were in broken family structure. There was no case that took place in an extended family structure. In studies in our country, it has been also stated that incest is more common in nuclear families, and a broken family structure poses a risk (Bozbeyoglu et al., 2009)(Frances \& Frances, 1976). 
In a study conducted according to the place of residence of those who were sexually assaulted in our country, it was found that $41.7 \%$ of the cases lived in provinces, $27.5 \%$ in districts, and $30.8 \%$ in villages and towns (Barutcu et al., 1999). In our study, it was observed that $55.9 \%$ (n: 19 ) of the cases lived in the city center, $32.4 \%$ (n: 11$)$ in the districts, and $11.8 \%$ $(\mathrm{n}: 4)$ in the villages.

In studies examining the distribution of incest according to the place where the incident occurred, it was observed that the victim and the defendant were in a shared house most of the cases (Davidson et al., 1996)(Y1lmaz\&Eryılmaz, 2016). Similarly, in our study, 47.1\% (n: 16) of the cases, the incident took place in their shared house where the victim and the defendant lived.

In studies showing the distribution of the alleged event's recurrence status, it is stated that the duration of abuse is longer in incest cases and it is usually repeated until the offense is exposed (Yildirim et al., 2014)(Ertur\&Yayc1, 2011)(Edwards \& Donaldson, 1989). Similarly, in our study it was found that $76.5 \%$ (n: 26) of the cases were abused more than once, repeatedly.

In studies examining the distribution of incest according to the alleged realization form, although most of the studies on domestic sexual abuse showing abuse in the form of touching and caressing $(45.8 \%)$, there are other studies that stating penetration is more common (Gencer et al., 2016)(Magalhaes et al., 2009)(Gunduz et al., 2011). In our study, it was observed that $14.7 \%$ (n: 5) of the cases had vaginal penetration, $14.7 \%$ (n: 5) had anal penetration, $14.7 \%$ (n: 5 ) of the cases had both anal and vaginal penetration, and $5.7 \%$ (n: 2) finger penetration, and it was observed that the cases were most frequently abused by touching-fondling-rubbing $(35.3 \%$, $\mathrm{n}: 12)$.

In studies on how the allegation of incest emerged, it was stated that the victim told the events to a family member (Quarshie et al., 2017) for the first time and most frequently to their mother, and second most frequently to a family elder whom they trust, and apart from their family, especially in our country, to their school counselor (Bozbeyoglu et al., 2009). In our study, in accordance with the literature, victims reported their situation to a family member $(\% 64,7, \mathrm{n}: 22)$, most commonly to their mother $(\% 35,3, \mathrm{n}: 12)$, only $5.9 \%$ (n: 2 ) directly notified the forensic units.

In a study showing the victim's family and relatives' attitude towards the victim and the judicial reporting process when they found out about the incest allegations, when people who were sexually assaulted disclosed the incident to their families, it was determined that $4.2 \%$ of them did not care, 5.8\% did not believe, and 10\% expressed reactions such as anger, humiliating, beating, and accusing the victim (Barutcu et al., 1999). Similarly, it was found in our study that a significant portion of the victim's first confidants (26.5\%, n: 9), all of whom were family members and relatives, did not participate in the judicial reporting process, expressed negative reactions, and the judicial notification was made by someone else. Among the victims who were attending school $(\% 55,8, \mathrm{n}: 19)$, it was determined that the most frequent notification was made by the school counselors $(57.8 \%, \mathrm{n}: 11)$.

In our study, when the distribution of the incest incidents was examined according to the period of reporting, it was observed that the period between when the alleged incident started and when the application to the judicial authorities was made, it took over a year for the victim to report the incident in most of the cases (\%41,2, n:14). When the reasons of the delayed reporting were evaluated, many different factors were caused to prevent the disclosure of incest, such as incest being mostly seen at a child age, the victim being small and vulnerable and can be easily intimidated by the threats of the assaulter, the victim's love and trust for their parent, who is also their assaulter in most of the incest cases, and fear of losing the assaulter's 
love, fear of what will happen to the them after the incident coming to light, the possibility of facing situations such as no one believing them and being blamed, being too young to comprehend what happened to them, seeing themselves as an accomplice, fear of society's reaction towards incest and fear of stigmatization, and lack of support from their family (Gregory-Bills \&Rhodeback, 1995)(Ozdemir, 2018).

While examining the distribution of the cases according to the biological sampling and obtaining evidence, even though it is known that the first 72 hours is very important for detecting biological material in sexual assault cases, in our study, it was found that only $8.8 \%$ (n: 3) of the patients were applied in the first 72 hours, and $85.3 \%$ (n: 29) were applied after more than 10 days. As a result of case-based evaluations, swab samples (23.5\%, n: 8) were taken, and biological evidence was obtained only in $8.8 \%$ (n: 3) of all cases.

Upon examining the distribution of the cases according to the colposcopic examination findings in our study, there were negative physical and ano-genital findings in $86.6 \%$ (n: 26) of a total of 30 cases who underwent ano-genital examination, non-acute old findings were detected in $13.4 \%$ ( $\mathrm{n}: 4$ ) of the cases. The fact that incest cases remain hidden for a long time and be found out late, decreases the possibility of detecting physical and genital examination findings as well as biological material on victim.

In many studies examining the distribution of sexual abuse / assault cases according to their psychiatric outcomes, it was found that most common mental disorder in people exposed to sexual abuse is Post Traumatic Stress Disorder (PTSD) at a rate of $25-70 \%$, followed by Major Depressive Disorder (MDD), Adjustment Disorders, Anxiety Disorders, Acute Stress Disorder and other disorders, as well as co-morbid diseases (Yildirim et al., 2014)(Kocak\&Alpaslan, 2015)(Karamese, 2018)(Skibinski, 1994). In addition, there are studies showing that the degree of closeness between the victim and the abuser is effective at the level of psychological trauma due to the abuse and may have more severe effects on people who have been subjected to domestic sexual abuse (Quarshie et al., 2017)(Edwards \& Donaldson, 1989). In our study, 61.8\% (n: 21) of the incest victims were diagnosed with psychiatric disorders, most common diagnose being PTSD (\%35,3, n:12). This was followed by MDD and Acute Stress Disorder, respectively.

In a study on the distribution of sexual abuse cases according to the number of centers where they were examined, due to the inadequacy of the centers and expert teams that can be consulted to, the children were subjected to repeated physical and mental examinations in different institutions and centers, and there is no multidisciplinary, holistic approach to such cases, which causes the children to re-experience the incident (Bozkurt et al., 2014). In the cases included in our study, it was found that $29.4 \%$ (n: 10) of the victims were also examined in another health institution before applying to us.

\section{LIMITATIONS}

Insufficient data belonging to the assaulter in the juridical files is one of the limitations of our study. In addition, the majority of the cases that applied to our department in our study were sent by the prosecution offices, and these cases being at the investigation stage causes us a lack of information about the judicial process of the cases, such as the outcome of the case, the decision at the court stage, whether the assaulter was punished or not.

\section{CONCLUSION}

Victims of incest being mostly children, being most often abused in their own home, and the school counselors being the most common reporters of the crime with the cases who continue their education demonstrates the importance of the schools. For this reason, it should be ensured that children continue their education and benefit from school counseling service, 
and all teachers, especially counselors and classroom teachers who communicate with the child in the primary school period, should be made aware of the matter of sexual abuse of the children. In addition, "Systematic sexual education" for children should be included in the curriculum. Since incest cases are mostly reported late, biological evidence, physical and genital examination findings cannot be obtained. The occurrence of psychopathology in most of the victims, shows the importance of mental health evaluation. In addition, it should be ensured that all procedures, including clinical treatment, are carried out in centers where a multidisciplinary approach can be provided, to prevent the retraumatization of the victim, due to repeated statements and examinations in the judicial process. 


\section{REFERENCES}

BARUTCU, N., YAVUZ, M. F., \& CETIN, G., 1999, Cinsel saldırı sonrası mağdurun karş1laştığ1 sorunlar, TheBulletin of Legal Medicine, 4(2), 41-53.

BASILE, K. C. \& SALTZMAN, L. E., 2002, Sexualviolencesurveillance; uniformdefinitionsandrecommended data element.

BOZBEYOGLU, A. C., KOYUNCU, E., SEZGIN, A. U., KARDAM, F., \& SUNGUR, A., 2009, Türkiye'de Ensest Sorununun Anlamak/Özet Rapor. Nüfusbilim Derneği ve Birleşmiş Milletler Nüfus Fonu. Damla Matbaacılık, Ankara.

BOZKURT, G., YORULMAZ, C., \& DÜZKAYA, D. S., 2014, Çocuklarda Cinsel İstismara Bağlı Travma Sonrası Stres Bozukluğu: Olgu Analizi, Sağlık Bilimleri Ve Meslekleri Dergisi, 1(2), 68-74.

BULUT, S., 2007, Çocuk cinsel istismarı hakkında bir derleme. Türk Psikolojik Danışma ve Rehberlik Dergisi, 3(28), 139-156.

CANAT, S., 1994, Ergenlerde aile içi cinsel taciz, Çocuk ve Gençlik Ruh Sağlı̆̆l Dergisi, 1(1), $18-22$.

COOPER, I.,\& CORMIER, B. M., 1982, Inter-generationaltransmission of incest. The CanadianJournal of Psychiatry, 27(3), 231235.https://doi.org/10.1177\%2F070674378202700312

CYR, M., WRIGHT, J., MCDUFF, P., \& PERRON, A., 2002, Intrafamilialsexualabuse: Brother-sisterincestdoes not differfromfather-daughterandstepfatherstepdaughterincest, Child Abuse\&Neglect, 26(9),

973.https://doi.org/10.1016/S0145-2134(02)00365-4

DAVIDSON, J. R., HUGHES, D. C., GEORGE, L. K., \& BLAZER, D. G., 1996, Theassociation of sexualassaultandattemptedsuicidewithinthecommunity, Archives of general psychiatry, 53(6), 550555.https://doi.org/10.1001/archpsyc.1996.01830060096013

DOKGÖZ, H. BİLGIN, N. G., KAR, H., TOROS, F., \& ÇEKİN, N., 2008, Çocuk Cinsel İstismar Olgusuna Yaklaşımda Çocuk Psikiyatrisi Değerlendirmesinin Önemi. Adli Psikiyatri Dergisi, 5(1), 37-41.

DOKGÖZ, H., POLAT O., 2019, Çocuk İstismarı ve İhmali. Dokgoz, H.,Adli Tıp ve Adli Bilimler (ss: 394). Ankara, Akademisyen Kitabevi.

EDWARDS, P. W.,\& DONALDSON, M. A., 1989, Assessment of symptoms in adultsurvivors of incest: A factoranalyticstudy of theResponsestoChildhoodIncestQuestionnaire, Child Abuse \&Neglect, 13(1), 101-110.https://doi.org/10.1016/0145-2134(89)90033-1

EKER, E., ÖZMEN, M., \& ÖZMEN, E., 1993, Cinsel sorunlar ve tedavileri el kitab1, Mentes Kitabevi, Istanbul.

ERTUR, E.,\& YAYCI, N., 2011, Erkek mağdur açısından ensest, Adli Tıp Dergisi, 25(3), 199214.

FISCHER, D. G.,\& MCDONALD, W. L., 1998, Characteristics of intrafamilialandextrafamilialchildsexualabuse. Child Abuse\&Neglect, 22(9), 915929.https://doi.org/10.1016/S0145-2134(98)00063-5

FRANCES, V., \& FRANCES, A., 1976, Theincesttabooandfamilystructure, FamilyProcess, 15(2), 235-244.https://doi.org/10.1111/j.1545-5300.1976.00235.x 
GENCER, Ö., ÖZBEK, A., ÖZYURT, G., \& KAVURMA, C., 2016, Çocuk Ve Ergenlerde Aile Dışı ve Aile İçi Cinsel İstismar Olgularının Karşılaştırılması, AnatolianJournal of Psychiatry/Anadolu Psikiyatri Dergisi, 17(1). DOI:10.5455/apd.1419190512

GÖK, S., 1991, Adli Tıp. 6.Bask1, Filiz Kitabevi, İstanbul, 383.

GÖKTEN, E. S., 2011, 2009-2011 Yılları Arasında Bir Devlet Hastanesinde Çocuk Psikiyatrisi Polikliniğine Yönlendirilen Adli Olgular,Çocuk ve Gençlik Ruh Sağllğı Dergisi, 18 (2).

GREGORY-BILLS, T.,\& RHODEBACK, M., 1995, Comparativepsychopathology of womenwhoexperiencedintra-familialversusextra-familialsexualabuse, Child abuse\&neglect, 19(2), 177-189.https://doi.org/10.1016/0145-2134(94)00115-b

GUNDUZ, T., KARBEYAZ, K., \& AYRANCI, U., 2011, Evaluation of theadjudicatedincestcases in Turkey: difficulties in notification of incestuousrelationships, Journal of forensicsciences, 56(2), 438443.https://doi.org/10.1111/j.1556-4029.2010.01662.X

GÜVENC, B., 2005, İnsan ve kültür, (11. basım). Remzi Kitabevi, İstanbul, 11. Basım.

İPEK, S., 1996, 1990-1995 y1lları arasında İstanbul adliyelerine yansıyan ensest olgularının psiko-sosyal açıdan incelenmesi, Yüksek Lisans Tezi, İ.Ü. Adli Tıp Enstitüsü Sosyal Bilimler Anabilim Dalı.

KAR, H., ÖZDEMİ, Ç., 2019, Cinsel Şiddet, Dokgöz, H., Adli Tıp ve Adli Bilimler (ss: 433). Ankara, Akademisyen Kitabevi.

KARAMEŞE, O., 2018, Kocaeli Üniversitesi Tıp Fakültesi Adli Tıp Anabilim Dalı'na Gönderilen Ensest Olgularının Değerlendirilmesi, Uzmanlık tezi, Kocaeli Üniversitesi Tıp Fakültesi.

KOÇAK, U.,\& ALPASLAN, A. H., 2015, Cinsel istismara uğrayan çocuk ve ergenlerin sosyodemografik özellikleri ve ruhsal değerlendirmesi, TheBulletin of Legal Medicine, 20(1), 27-33.

MAGAlHÃES, T., TAVEIRA, F., JARDIM, P., SANTOS, L., MATOS, E., \& SANTOS, A., 2009, Sexualabuse of children. A comparativestudy of intraandextrafamilialcases. Journal of forensicand legal medicine, 16(8), 455459.https://doi.org/10.1016/j.jflm.2009.05.007

MAYER, A., (1983). Incest: A treatmentmanualfortherapywithvictims, spousesandoffenders. HolmesBeach, FL: Learning Publications.

ÖZDEMİR, P., 2018, Ensest Mağduru Çocukların Adli Dosyalarının Sosyal Hizmet Bakış Açısıyla İncelenmesi Ve Müdahale Modelinin Geliştirilmesi, Doktora Tezi, Türkiye Cumhuriyeti Ankara Üniversitesi Sağlık Bilim Enstitüsü Ankara.

POLAT, O., 2006, Aile içi cinsel istismar: Ensest, Nokta Kitap, 1. Baskı, 9789759146801.

QUARSHIE, E. N. B., OSAFO, J., AKOTİA, C. S., PEPRAH, J., \& ANDOH-ARTHUR, J., 2017, Someepidemiologicalcharacteristics of perpetratorsandvictims of incest in contemporaryGhana: Analysis of mediareports, Journal of childsexualabuse, 26(2), 121-139.https://doi.org/10.1080/10538712.2016.1277573

SEARCH, G., 1993, Son Tabu, Çocuklara karsı cinsel suçlar. Sarmal Yayınevi, İstanbul, 1. Bask1.

SEZGIN, A. U., 1993, Ensestinpsikososyal ve adli yönden İncelenmesi, Yayımlanmamış Yüksek Lisans Tezi, Ístanbul Üniversitesi Adli Tip Estitüsü. 
SIMPSON, JA \& WEINER, ESC., 1989, Dictionary, O. E. Oxford englishdictionary.

SKIBINSKI, G. J., 1994, Intrafamilialchildsexualabuse: Interventionprogramsforfirst time offendersandtheirfamilies, Child abuse\&neglect, 18(4), $367-$ 375.https://doi.org/10.1016/0145-2134(94)90039-6

TÜTÜNCÜLER, A., 2011, Adli Tıp Kurumu'na yansıyan ensest olguların retrospektif değerlendirilmesi, Uzmanlık Tezi, Adalet Bakanlığı Adli Tıp Kurumu Başkanlığı, İstanbul.

TÜRK DİL KURUMU, Büyük Türkçe Sözlük,https://sozluk.gov.tr/

YILDIRIM, A., OZER, E., BOZKURT, H., OZSOY, S., ENGINYURT, O., EVCUMAN, D., ... \& KUYUCU, Y. E., 2014, Evaluation of socialanddemographiccharacteristics of incestcases in a universityhospital in Turkey,Medicalsciencemonitor, internationalmedicaljournal of experimentalandclinicalresearch, 20, 693.https://dx.doi.org/10.12659\%2FMSM.890361

YILMAZ, R.,\& ERYILMAZ, A., 2016, Bülent Ecevit Üniversitesi Hastanesinde Değerlendirilen Ensest Olgularının Sosyodemografik Özellikleri, TheBulletin of Legal Medicine, 21(3), 167-171. 